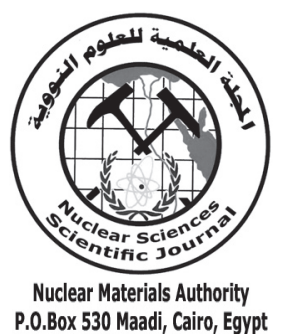

ISSN 2314-5609

Nuclear Sciences Scientific Journal

vol. 2, p 153 - 163

2013

\title{
SUCCESSIVE RECOVERY OF COPPER AND URANIUM FROM CARBONATE - RICH LATOSOL, UM BOGMA FORMATION, ABUTHOR LOCALITY, SOUTH WESTERN SINAI, EGYPT
}

\author{
ENASS M. EL-SHEIKH, MAYSA M. AMIN, SAMY K. AITA and AFAF A. REZK \\ Nuclear Materials Authority,P.O.Box 530 El Maadi, Cairo, Egypt
}

\begin{abstract}
A technological sample of a copper/ uranium mineralization in carbonate rich latosol rock sequence of Um Bogma Formation Abu Thor locality at southwestern Sinai, Egypt, has been properly processed. The working sample assaying $12.5 \% \mathrm{CuO}$ and $875 \mathrm{ppm} \mathrm{U}$ was subjected to adipic acid leaching for copper followed by bioleaching of uranium in a manner to avoid excessive acid consumption in the classical leaching procedure. It is thus possible to achieve leaching efficiencies of $95 \%$ for $\mathrm{Cu}$ in the first stage and $82 \%$ for $\mathrm{U}$ in the second stage. From the two separately obtained leach liquors of $\mathrm{Cu}$ and uranium, pure products have conveniently been prepared. Accordingly, $\mathrm{Cu}$ adipate product was first prepared by crystallization,followed by acid dissolution and alkali precipitation of copper hydroxide. In case of uranium, the impure precipitate of the bioleach liquor is purified via Amberlite IRA-400 anion exchanger resin.
\end{abstract}

\section{INTRODUCTION}

An extensive exploration program conducted by the Nuclear Materials Authority for uranium and nuclear raw materials in Egypt has led to the discovery of several uranium mineralizations in different regions. Recovery of uranium and possible associated valuable elements (e.g. Th, V, Mo, Cu, REEs,etc) is indeed another concern of the Nuclear Materials Authority. Among the discovered mineralizations, the Carboniferous rock sequence at SW Sinai represents indeed a promising terrain for uranium and other valuable economic metals in association with Um Bogma Formation .The latter includes mainly $\mathrm{Cu}, \mathrm{V}, \mathrm{REE}$ besides the famous $\mathrm{Fe} / \mathrm{Mn}$ deposits in different concentrations in several localities and rock facies of this Formation; viz, Allouga, Talat Selim, Abu Thor, etc.

The main object of this study is to recover both uranium and copper from the carbonaterich latosol of Um Bogma Formation at $\mathrm{Abu}$
Thor locality. In this regard, several studies have previously been undertaken using sulfuric acid leaching and have proven that both metal values are amenable to acid leaching. However, this has been realized on the expense of relatively high acid consumption (El-Hazek et al., 2008 and Amer et al., 2010 etc.). This is due to the fact that the carbonate content of these ore materials is generally very high as it exceeds 50-60\%. On the other hand ,separation of $\mathrm{Cu}$ and $\mathrm{U}$ from their leach liquors in these studies has mainly been undertaken by several techniques e.g anion exchange resins, solvent extraction, cementation, etc.

To realize the objectives of this work, a technological sample assaying $12.5 \% \mathrm{CuO}$ and $875 \mathrm{ppm}$ uranium has been collected from the mentioned carbonate- rich latasol ore material of Abu Thor locality. To avoid excessive consumption of sulfuric acid, adipic acid as an organic acid for $\mathrm{Cu}$ leaching is applied while for the associated uranium, bioleaching is applied upon the ore residue left behind. 
As the matter of fact, the versatile $\alpha-$, wdicarboxylic acid can accept various modes of binding such as monodendate, bi-dendate chelates or bridging ligand to form polymeric species with metal centers (Oldaham, 1987). Structural and other physico-chemical studies of monocarboxylate metal complexes are well known. Thus, Suresh(2009) has been interested in the structural chemistry of $\mathrm{Cu}$ (II) and $\mathrm{Co}$ (II) ternary coordination polymers by utilizing the versatile coordination modes of carboxylate ligand with metal center and various $\mathrm{N}$-donor ligands such as bipyridyl, imidazole, methyl imidazole etc. Typically, adipic acid $[\alpha-, \omega ́$-dicarboxylate aliphatic acid $\left.\left(\mathrm{CH}_{2}\right)_{4}(\mathrm{COOH})_{2}\right]$ could react with copper to form $\mathrm{Cu}$ (II) adipate: $\mathrm{Cu}\left(\mathrm{CH}_{2} \mathrm{CH}_{2} \mathrm{COO}\right)_{2}$. The latter has previously been prepared and reported by Burken (1950).

From the industrial perspective, adipic acid is indeed the most important dicarboxylic acid. About 2.5 billion kilograms of this white crystalline powder are annually produced, mainly as a precursor for the production of nylon. Adipic acid is a valuable raw material used in the production of fibers, lubricants, plasticizers, and food additives as well as in the production of intermediates for pharmaceuticals, insecticides, and bactericides. Conventionally, it is manufactured by oxidation of cyclohexanone / cyclohexanol, by hydrogenation of phenol, or more commonly, by oxidation of cyclohexane (Davis et al., 1991and Castellan et al.,1991).

On the other hand, uranium recovery in this work is studied through bioleaching technique which depends on adopting the organic acids producing from the microorganisms through proper bioleaching process. The latter is actually based on the ability of the produced microorganisms (bacteria and fungi) to transform several compounds to soluble and extractable elements, which can be recovered (Saeed et al., 2002). Recently, several works as Ibrahium, 2007and Amin, 2008 have been made to utilize acidophilic heterotrophs (bac- teria and fungi) for metals extraction from ores which contain calcite $\left(\mathrm{CaCO}_{3}\right)$ and dolomite $\left[\mathrm{CaMg}\left(\mathrm{CO}_{3}\right)_{2}\right]$ as gangue minerals. Aspergillus niger has actually been found to produce several organic acids as citric and oxalic that can serve as leaching agents for the solubilization of metals.

Bioleaching has actually been widely used in the commercial extraction of uranium, copper and gold from their ores beside being exploited in the extraction of other base and rare noble metals as zinc, cobalt, nickel, molybdenum, gallium, germanium etc. In some cases, these processes have attained the phase of pilot scale experiments (Ehrlich and Brierley, 1990). Metal dissolution is achieved through a series of reactions including acidolysis, complex and chelate formation (Brandle et al., 2001).

\section{MINERALOGICAL CHARACTERISTICS}

The Carboniferous rock sequence of $\mathrm{Abu}$ Thor area (Figs.1 \& 2) is actually represented by two Formations namely: a lower Um Bogma Formation and an upper Abu Thora Formation. The lower Um Bogma Formation ( ab. $27 \mathrm{~m}$ thick) is classified into two members; viz a lower Mn ore member of karstified shallow marine carbonate facies hosting $\mathrm{Mn}$ ore together with $\mathrm{Fe}, \mathrm{Cu}$ and $\mathrm{U}$ minerals and an upper dolostone-shale member (El Sharkawi et al., 1990). At Abu Thor area uranium and copper mineralizations are recorded within intra-Carboniferous paleokarst profile of Um Bogma Formation. The origin of copper and uranium mineralizations of Um Bogma Formation was discussed by many authors including Hilmy and Mohsen (1965), El Reedy et al. (1988), Dabbour and Mahdy (1988), ElSharkawi et al. (1990), Hussein et al. (1992), Aita (1996) and Abd El Moneim et al. (1997). Recent studies by Mira and Aita (2009) postulated that the Carboniferous stratabound $\mathrm{Cu}$ and $\mathrm{U}$ mineralizations in the form of copper carbonate, chloride, silicate, sulphate and phosphate minerals are of supergene origin and have been concentrated by pedogenic processes and latosol formation. 


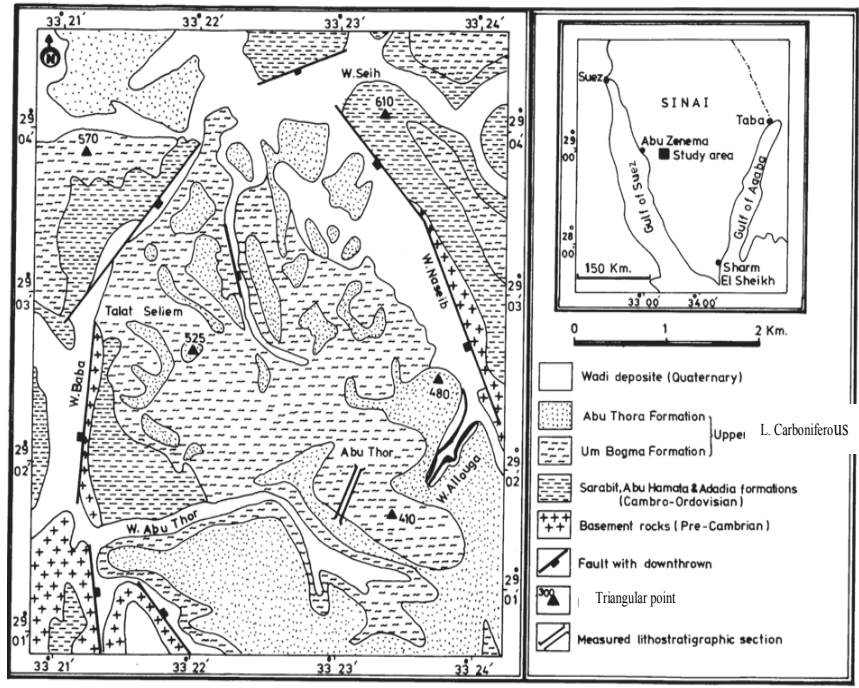

Fig. 1: The modified geologic Map , Abu Thor Locality (After Mira and Aita, 2009 )

Mira and Aita (Op cit.) subdivided the pa-

EXPERIMENTAL

leokarst profile in Abu Thor locality into three main deep weathering soil horizons namely: a lower parent carbonate horizon, a middle subsoil horizon and an upper latosol horizon. The latosol horizon is classified into a lower laminated siltstone subhorizon and an upper organic-rich mudstone subhorizon containing the $\mathrm{Cu}$ and $\mathrm{U}$ mineralizations and from which the present technological sample is collected. Generally, the identified $\mathrm{Cu}$ - and U-bearing minerals in the studied area include: atacamite, paratacamite, rosasite, zircon, monazite and zippeite (Mira and Aita, 2009). The associated minerals in the host carbonate rocks include essentially malachite $4\left[\mathrm{Cu}_{2}(\mathrm{OH})_{2} \mathrm{CO}_{3}\right]$, calcite, dolomite, quartz, hematite besides variable amounts of rutile, jarosite, goethite, crednerite, gypsum, ankerite, kaolinite, alunite, gibbsite, hausmanite, pyrolusite, phosphosiderite, and lawrencite (Aita, 1996).

\section{Material}

The collected technological sample weighing about $5 \mathrm{~kg}$ is found to include visible green and bright colored $\mathrm{Cu}$ and $\mathrm{U}$ mineralizations (Fig.2). In the field, the recorded copper and uranium minerals appear in different forms such as lenticular masses (up to $40 \mathrm{~cm}$ long and $10 \mathrm{~cm}$ thick), discrete pockets (up to $20 \mathrm{~cm}$ in diameter), nodules, veinlets and spots. The host rock of these minerals consists mainly of alternating multicolored layers of kaolinitic green mudstone and altered shaly marl intermixed with organic-rich earthy soil materials.

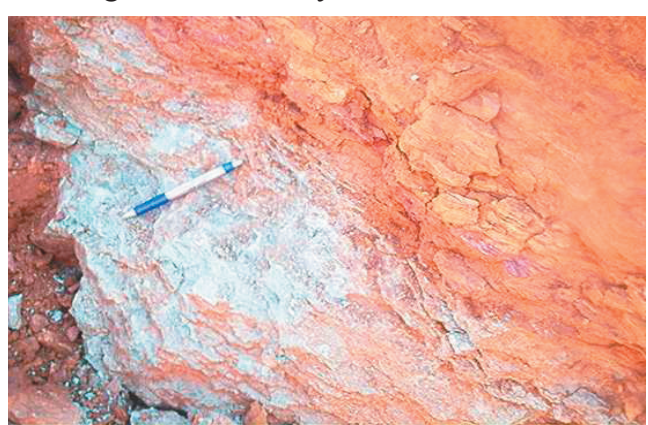

Fig.2: Green copper and uranium mineralizations of the carbonate-rich latosol horizon, Abu Thor locality 


\section{Leaching Procedures}

\section{Adipic acid leaching of copper}

Several leaching experiments for copper have actually been performed using adipic acid to optimize the relevant leaching factors. In these experiments, a $30 \mathrm{~g}$ of the working $\mathrm{Cu} / \mathrm{U}$ ore ground to -200 mesh size is mixed with a suitable volume of adipic acid of various concentrations. The slurry is then agitated for a fixed time at a certain temperature after which the treated slurry is filtered and the residue left behind is thoroughly washed with distilled water and both filtrate and washings were made up to volume before analysis.

\section{Microbiological leaching of uranium}

For this purpose, a strain of Aspergillus niger isolated from the ferruginous siltstone ore in Allouga area, southwestern Sinai was properly prepared using a culture medium composed of Dox liquid medium of the following concentration (g/l): $\mathrm{NaNO}_{3}, 2 ; \mathrm{KH}_{2} \mathrm{PO}_{4}, 1$; $\mathrm{MgSO}_{4} .7 \mathrm{H}_{2} \mathrm{O}, 0.5, \mathrm{KCl}, 0.5, \mathrm{FeSO}_{4} .5 \mathrm{H}_{2} \mathrm{O}$ : trace and sucrose: 30 . The $\mathrm{pH}$ value of the medium is adjusted at 6.5 before autoclaving at $1.5 \mathrm{~atm}$. for $20 \mathrm{~min}$.

The bioleaching experiment was carried out in one liter Erlenmyer flask containing 600 $\mathrm{ml}$ of the prepared $A$. niger metabolite. The latter was analyzed for organic acids in culture filtrate by Gas Chromatography at the Regional Center for Mycology and Biotechnology, Al Azhar Univ., Cairo, Egypt. The initial pH of the used metabolite ranges from 2.5-3 and to which $300 \mathrm{~g}$ of sample the $\mathrm{Cu}$-leached ore residue after adipic leaching was added. The flask was incubated on a mechanical shaker at $100 \mathrm{rpm}$ for 24 hours and the obtained filtrate was subjected to uranium determination.

\section{Analytical Procedures}

Proper quartering of the technological sample was performed after its grinding to less than 200 mesh size to obtain a representative sample being subjected to complete chemical analysis of both major and trace elements content. For the former the conventional wet chemical technique was applied (Shapiro and Brannock, 1962). Whereas $\mathrm{SiO}_{2}, \mathrm{Al}_{2} \mathrm{O}_{3}, \mathrm{TiO}_{2}$ and $\mathrm{P}_{2} \mathrm{O}_{5}$ were determined using relevant spectrophotometic methods, the contents of $\mathrm{Na}$ and $\mathrm{K}$ were determined by a flame photometric technique. Total $\mathrm{Fe}$ as $\mathrm{Fe}_{2} \mathrm{O}_{3}, \mathrm{MgO}$ and $\mathrm{CaO}$ were determined by titration methods. The loss on ignition (L.O.I) was determined gravimetrically. The estimated error for major constituents is not more or less than $1 \%$.

The trace elements V, Cr, Ni, Zn, Ga, Rb, $\mathrm{Sr}, \mathrm{Y}, \mathrm{Zr}, \mathrm{Nb}, \mathrm{Pb}$ and $\mathrm{Cu}, \mathrm{Ba}$ were analyzed at the laboratories of the Nuclear Materials Authority by the X-ray fluorescence technique (XRF) using Philips Unique II unit with automatic sample changer PW 1510 (30 position), connected to a computer system using X-40 program for spectrometry. The detection limit of the measured elements by XRF technique was estimated to be $5 \mathrm{ppm}$.

To follow the leaching and recovery efficiencies, the different stream solutions were subjected to $\mathrm{Cu}$ and $\mathrm{U}$ analysis. For the former, an atomic absorption spectrophotometer (AAS) Unicam 969, England was used while for uranium the oxidimetric titration method against ammonium metavanadate was used after its reduction. Finally, the obtained products have been qualitatively analyzed using ESEM-EDX analysis.

\section{RESULTS AND DISCUSSIONS}

\section{Chemical Composition of the Working} Technological Sample

The complete chemical analysis of the working technological Abu Thor ore sample is given in Table (1) including its $\mathrm{CuO}$ content. From the latter, it is obviously evident that besides the high level of the loss on ignition, it contains a high content of both $\mathrm{Ca}$ and $\mathrm{Cu}$ metal which exist as carbonate minerals reflecting a high carbonate content. 
Table 1 : The chemical analysis of the working Abu Thor technological ore sample

\begin{tabular}{|c|c|c|c|}
\hline Component & wt. $\%$ & Component & wt. $\%$ \\
\hline $\mathrm{SiO}_{2}$ & 14.50 & $\mathrm{~K}_{2} \mathrm{O}$ & 0.35 \\
\hline $\mathrm{TiO}_{2}$ & 0.17 & $\mathrm{P}_{2} \mathrm{O}_{5}$ & 0.01 \\
\hline $\mathrm{Al}_{2} \mathrm{O}_{3}$ & 5.36 & $\begin{array}{r}\text { L.O.I } \\
\left(550^{0} \mathrm{C}\right)\end{array}$ & 5.60 \\
\hline $\mathrm{Fe}_{2} \mathrm{O}_{3}$ & 1.93 & $\begin{array}{r}\text { L.O.I . ( 550- } \\
\left.1000^{\circ} \mathrm{C}\right)\end{array}$ & 29.10 \\
\hline $\mathrm{MnO}$ & 3.25 & $\mathrm{SO}_{4}$ & 2.00 \\
\hline MgO & 3.03 & $\mathrm{CuO}$ & 12.50 \\
\hline $\mathrm{CaO}$ & 23.50 & $\mathrm{Cl}$ & 0.60 \\
\hline $\mathrm{Na}_{2} \mathrm{O}$ & 0.01 & Total & 101.9 \\
\hline
\end{tabular}

The principal possible mineralogical composition has been calculated in the light of the chemical composition and has shown the presence of about $67 \%$ of carbonate minerals. These include $13.8 \%$ dolomite, $33.6 \%$ calcite and $19.4 \%$ malachite. The latter is calculated according to the analysis of $\mathrm{CuO}$ content and its equivalent of $\mathrm{CO}_{2}$. As a matter of fact, the presence of such high carbonate content has been behind the choice of adipic acid leaching of copper and the bioleaching of uranium in order to avoid the excessive consumption of sulfuric acid in classical leaching procedures.

On the other hand, another part of the technological sample was subjected to X-ray fluorescence for the analysis of some trace elements (Table 2). The latter shows that U attains $875 \mathrm{ppm}$ while $\mathrm{V}$ assays $880 \mathrm{ppm}$ besides interesting values of $\mathrm{Zn}, \mathrm{Cr}, \mathrm{Ni}$ and $\mathrm{Ga}$ ; namely 317, 182, 88 and 27 ppm, respectively.

\section{Results of Chemical Processing}

\section{Copper recovery}

\section{Adipic acid leaching}

Effect of adipic acid concentration: The effect of adipic acid concentration was studied between 0.1 and 0.9 mole , while the other leaching factors were fixed at -200 mesh ore
Table 2: XRF analytical results of the interesting trace elements in the working Abu Thor technological ore sample

\begin{tabular}{lrrr}
\hline $\begin{array}{l}\text { Trace } \\
\text { element }\end{array}$ & ppm & $\begin{array}{r}\text { Trace } \\
\text { element }\end{array}$ & ppm \\
\hline Ba & 1282 & Pb & 160 \\
V & 880 & Cr & 182 \\
Ni & 88 & Sr & 740 \\
Nb & 43 & Ga & 27 \\
Zn & 317 & Zr & 310 \\
Rb & 83 & U & 875 \\
Y & 101 & & \\
\hline
\end{tabular}

size, half an hour agitation time, $50^{\circ} \mathrm{C}$ leaching temperature and $1 / 3$ solid-liquid $(\mathrm{S} / \mathrm{L})$ ratio. The leaching efficiencies of both uranium and copper given in Table (3) indicate that the best conc. of adipic acid is 0.5 mole for copper leaching. Under these conditions, the leaching efficiency of copper has attained up to $95.3 \%$ with which uranium dissolution was about $6.5 \%$. Higher concentrations of adipic acid did not markedly affect the copper leaching efficiency, however uranium leaching increased where at 0.9 mole, it attained $13 \%$.These results indicate that uranium solubility in adipic acid is greatly limited ; a matter which would enable its selective separation from copper during leaching. The obtained data are actually in agreement with the results obtained by Bassi et al. (1988) who have reported that solid-solid reactions of basic copper carbonate with adipic acids gave the corresponding copper (II) carboxylate chelates . Formation of $\mathrm{Cu}$ adipate can be represented by the following successive equations (Fessenden and Fessenden, 1982; Bassi and Kalsi, 1977):

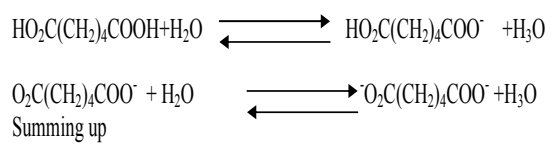

$\mathrm{HO}_{2} \mathrm{C}\left(\mathrm{CH}_{2}\right)_{4} \mathrm{COOH}+2 \mathrm{H}_{2} \mathrm{O}+2 \mathrm{Cu}^{++}$ $\mathrm{Cu}_{2}\left(\mathrm{CH}_{2} \mathrm{CH}_{2} \mathrm{COO}\right)_{2}+2 \mathrm{H}_{3} \mathrm{O}$ 
Table 3: Effect of adipic acid concentration on copper and uranium leaching efficiencies from Abu Thor technological ore sample

\begin{tabular}{lcr}
\hline $\begin{array}{l}\text { Adipic acid } \\
\text { concentration, } \\
\text { mole }\end{array}$ & \multicolumn{2}{c}{ Leaching efficiency, $\%$} \\
\hline 0.1 & Copper & Uranium \\
0.2 & 63.3 & 4.21 \\
0.3 & 75.9 & 5.17 \\
0.4 & 83.2 & 5.92 \\
0.5 & 90.8 & 6.33 \\
0.6 & 95.3 & 6.49 \\
0.7 & 98.2 & 7.45 \\
0.8 & 98.3 & 8.20 \\
0.9 & 98.3 & 10.00 \\
\hline
\end{tabular}

Effect of agitation time: The effect of leaching time upon $\mathrm{Cu}$ and $\mathrm{U}$ leaching efficiencies is studied in the range from 10 to 60 minutes, while the other leaching conditions are fixed at 0.5 mole adipic acid concentration, -200 mesh size ore material, a leaching temperature of 50 ${ }^{\circ} \mathrm{C}$ and using a solid / liquid ratio of $1 / 3$. The obtained data shown in Table (4) reveal that a high copper leaching efficiency exceeding $95 \%$ occurs within the first $30 \mathrm{~min}$. associated with about $6.5 \%$ uranium leaching efficiency. Therefore, it can be concluded that thirty minutes are adequate to almost complete $\mathrm{Cu}$ leaching using 0.5 mole adipic acid concentration.

Table 4: Effect of leaching time upon copper and uranium leaching efficiencies from $\mathrm{Abu}$ Thor technological ore sample

\begin{tabular}{lrr}
\hline Time/minutes & \multicolumn{2}{c}{ Leaching efficiency, \% } \\
& Copper & Uranium \\
\hline 10 & 33.18 & 1.30 \\
20 & 71.90 & 4.20 \\
30 & 95.30 & 6.49 \\
45 & 96.70 & 7.43 \\
60 & 96.98 & 8.25 \\
\hline
\end{tabular}

Effect of temperature : Four adipic acid leaching experiments have been performed to investigate the effect of leaching temperature in the range from room (about $25^{\circ} \mathrm{C}$ ) up to $100{ }^{\circ} \mathrm{C}$. In these experiments, the other leaching conditions are fixed at -200 mesh size ore material, 0.5 mole adipic acid concentration for $30 \mathrm{~min}$. agitation time and using a $1 / 3 \mathrm{~S} /$ $\mathrm{L}$ ratio. The obtained data are shown in Table (5) and reveal actually the importance of temperature to obtain a high leaching efficiency of copper. Working at room temperature under the mentioned conditions did not leach more than $10 \%$ of $\mathrm{Cu}$ while that of uranium amounted to only $0.5 \%$. Increasing the leaching temperature to $50^{\circ} \mathrm{C}$ has increased the leaching efficiency of copper to $95.3 \%$ and its further increase to $70^{\circ} \mathrm{C}$ increased the $\mathrm{Cu}$ leaching efficiency to $97.18 \%$, while that of uranium increased to $7.31 \%$ and after which there has been only a slight increase in the leaching efficiencies. It can thus be mentioned that the optimum leaching temperature of $\mathrm{Cu}$ using 0.5 mole of adipic acid under the above mentioned conditions would be $50^{\circ} \mathrm{C}$.

Table 5: Effect of leaching temperature upon copper and uranium leaching efficiencies from $\mathrm{Abu}$ Thor technological ore sample

\begin{tabular}{lrr}
\hline Temperature, & Leaching efficiency, $\%$ \\
${ }^{\circ}$ C & Copper & Uranium \\
\hline 25 & 10.00 & $0.5 \%$ \\
50 & 95.30 & 6.49 \\
70 & 97.18 & 7.31 \\
100 & 97.30 & 8.1 \\
\hline
\end{tabular}

Effect of the solid/liquid ratio :The effect of the solid/liquid ratio upon copper and uranium leaching efficiencies was studied between $1 / 3$ and $1 / 5$. In these experiments, the fixed leaching conditions involved -200 mesh size ore material, 0.5 mole adipic acid concentration for $30 \mathrm{~min}$. agitation time at $50{ }^{\circ} \mathrm{C}$ as leaching temperature.. From the obtained leaching efficiencies given in Table (6), it is found that beyond $1 / 3 \mathrm{~S} / \mathrm{L}$ ratio, only a slight steady increase in the leaching efficiencies of 
both copper and uranium has been achieved. Accordingly, a solid/liquid ratio of $1 / 3$ would be considered as optimum at which the leaching efficiency of copper and uranium attained 95.3 and $7.31 \%$, respectively.

Table 6: Effect of solid/liquid ratio upon copper and uranium leaching efficiencies from Abu Thor technological ore sample

\begin{tabular}{lrr}
\hline $\begin{array}{l}\text { Solid/liquid } \\
\text { ratio }\end{array}$ & \multicolumn{2}{c}{ Leaching efficiency\% } \\
\hline $1 / 3$ & Copper & Uranium \\
$1 / 4$ & 95.30 & 6.49 \\
$1 / 5$ & 97.38 & 7.39 \\
\hline
\end{tabular}

From the above studied leaching factors of Abu Thor technological ore sample, it can be concluded that the optimum leaching conditions for dissolving about $95 \%$ of copper associated with about $6.5 \% \mathrm{U}$ would be summarized as follows:

Grain size : -200 mesh.

Acid concentration : 0.5 mole

Leaching time : 30 minute

Leaching temperature : $50^{\circ} \mathrm{C}$.

Solid/liquid ratio $: 1 / 3$

\section{Preparation of copper product}

For studying the recovery procedures of copper from the working sample, a proper 3 liter adipate leach liquor was prepared from 1 $\mathrm{Kg}$ of the working ore sample using the above mentioned determined optimum leaching conditions. Chemical analysis of $\mathrm{CuO}$ and $\mathrm{U}$ in this liquor is found to attain $39.7 \mathrm{~g} / 1$ and only $21.3 \mathrm{mg} / 1$ respectively. From this liquor, blue copper adipate crystals have been obtained by its proper cooling for half an hour. The obtained crystals (Fig. 3) have been subjected to infrared analysis to confirm their structure.

Accordingly, the obtained IR spectra (Fig. 4) of the blue crystals show a broad peak at 3,430 $\mathrm{cm}^{-1}$, which is attributed to the characteristic stretching vibration of hydroxylate $\mathrm{O}-\mathrm{H}$. The broad band ranging from 500 to $900 \mathrm{~cm}^{-1}$ can be attributed to the disordered distribution of vacancies and the continuous distribution of bond length in an amorphous material (Shek et al,1997). These results reveal that abundant surface hydroxyl groups exist in the prepared copper adipate crystals. On other hand ,to prepare a marketable $\mathrm{Cu}$ product, the obtained copper adipate was easily converted to hydroxide or oxide by dissolution in one mole sulfuric acid followed by precipitation of $\mathrm{Cu}(\mathrm{OH})_{2}$ using ammonia solution at $\mathrm{pH}$ 5.5. The obtained hydroxide product has been subjected to proper analysis using the ESEMEDX technique (Fig. 5) where $\mathrm{Cu}$ assays about $97 \%$ indicating its almost high purity .

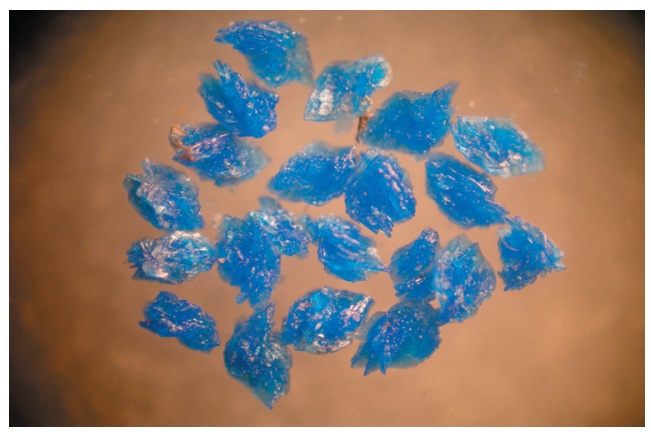

Fig.3: Prepared copper-adipate crystals

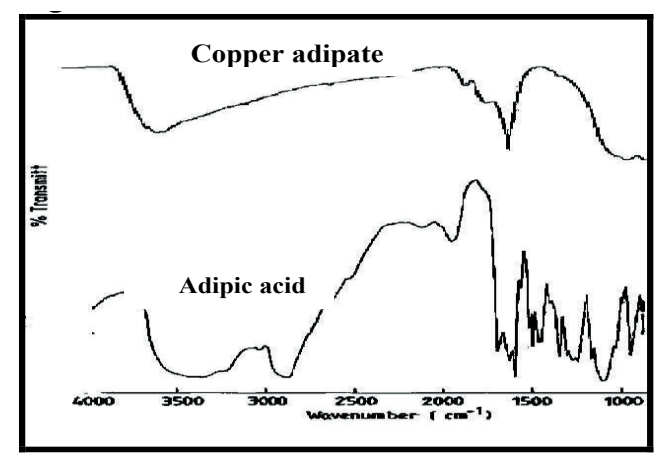

Fig. 4: Infrared spectra of copper-adipate crystals

\section{Uranium recovery}

\section{Microbiological leaching}

The main part of $U$ left behind in the ore residue after adipic acid leaching of $\mathrm{Cu}$ was then directed to bio-leaching using Aspergillus niger. However before leaching, the prepared Aspergillus niger metabolites was first 
subjected to proper chromatographic analysis (Fig. 6) indicating that it secretes in the growth media some organic acids including formic (about 40\%), citric (about 35\%) beside acetic and oxalic acids.

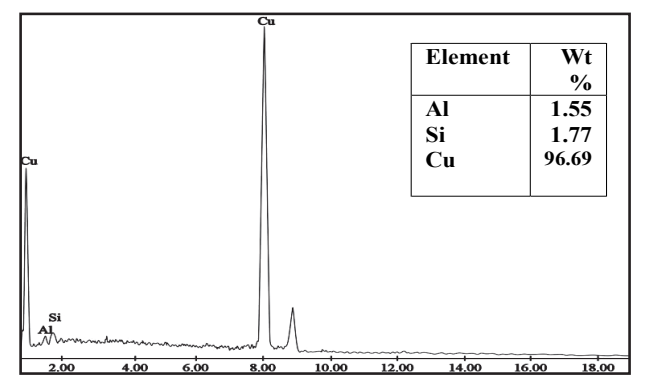

Fig. 5: ESEM with EDX analysis of the prepared copper hydroxide product

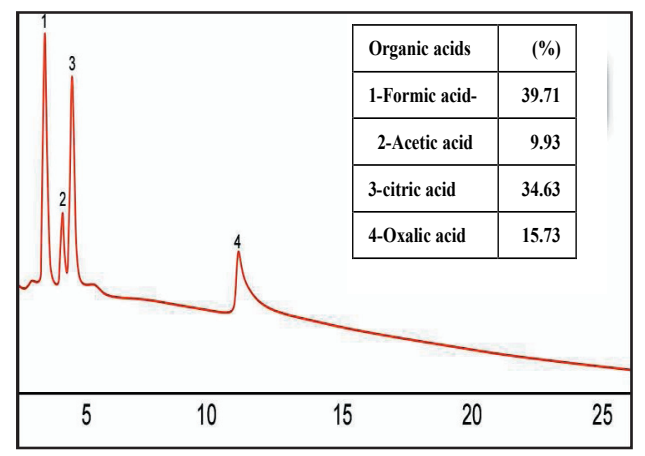

Fig.6: Typical organic acids chromatograph of A.niger grown on Dox liquid medium

According to Hefnawy et al. (2002 \&2003), the bioleaching process could be achieved using a solid/ $A$. niger metabolite ratio of 1:2 and adjusting the $\mathrm{pH}$ of the solution at 2.5-3. for an incubation time of 24 hours at $100 \mathrm{rpm}$. It is interesting to mention herein that the uranium content in $300 \mathrm{~g}$ of the copper-leached residual ore sample attains about $250 \mathrm{mg}$ besides about $1814 \mathrm{mg}$ of copper. The obtained bioleach liquor solution $(600 \mathrm{ml})$ was subjected to proper analysis and was found to assay about $335 \mathrm{ppm}$ for uranium beside $60 \mathrm{ppm}$ copper indicating leaching efficiencies of 81.83 and $1.98 \%$, respectively.

\section{Preparation of uranium product}

As a matter of fact, uranium would precipitate from the obtained bioleach liquor after arising its $\mathrm{pH}$ to 7.5 using $10 \% \mathrm{NaOH}$ and the obtained product has then been subjected to proper analysis using the ESEM-EDX. From the latter shown on Fig. (7), it is found that U assay in the product amounted to only $32.93 \%$ $\mathrm{U}$ and being associated with several impurity elements; namely $\mathrm{Al}, \mathrm{Fe}$ and $\mathrm{P}$ and some $\mathrm{Na}$. It is significant to mention herein that $\mathrm{Cu}$ is not present in this precipitate reflecting its low content in the working bioleach liquor as is previously mentioned.

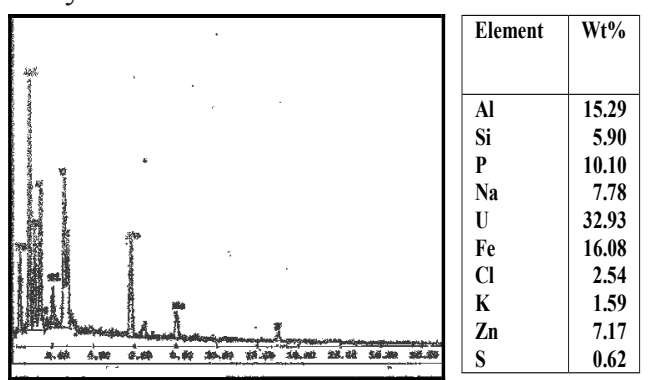

Fig.7: ESEM-EDX analysis of uranium concentrate, sodium diuraniate product directly precipitated from the bioleach liquor at $\mathrm{pH} 7.5$

In order to improve the quality of the obtained impure uranium concentrate, the latter $(0.674 \mathrm{~g})$ is dissolved in 1 molar sulfuric acid and the obtained solution is subjected to proper concentration and purification using anion exchange resin which is quite selective for uranium recovery from the obtained sulfate leach liquor. In the latter solution, the competing anions include mainly $\mathrm{SO}_{4}^{-2}$ and $\mathrm{HSO}_{4}^{-}$ and therefore uranium would be better adsorbed at $\mathrm{pH}$ value exceeding 1.8 while below this value, $\mathrm{HSO}_{4}^{-}$would be strongly adsorbed. (Merritt, 1971; Preuss and Kurrin, 1965).

In this work, $2.5 \mathrm{ml}$ of wet settled resin (wsr) Amberlite IRA- 400 anion exchanger was packed in a suitable Pyrex glass column $(0.5 \mathrm{~cm}$ diameter) over a glass wool plug. The prepared uranium sulfate solution was firstly treated with $5 \%$ of $\mathrm{NaOH}$ to adjust its $\mathrm{pH}$ to 1.8 followed by its passing through the prepared resin column using a contact time of $3 \mathrm{~min}$. (0.33 ml/min.). The loaded uranium 
is then eluted from the resin using $1 \mathrm{~N} \mathrm{NaCl}$ acidified with $0.1 \mathrm{M}$ sulfuric acid. An eluate volume of $200 \mathrm{ml}$ is collected at the end of the elution process and is found to assay 1000 ppm resulting to an elution efficiency $90 \%$. From the obtained eluate, uranium is precipitated by $\mathrm{NH} 4 \mathrm{OH}$ as ammonium diuranate at pH 5.5 and the product is subjected to analysis using ESEM-EDX (Fig. 8) from which U assay increased up to about $87 \%$.

\section{CONCLUSION}

Proper processing has been achieved for the $\mathrm{Cu} / \mathrm{U}$ mineralization hosted in carbonate-rich latosol horizon of the Carboniferous Um Bogma Formation at southwestern Sinai. Thus, to avoid excessive sulfuric acid consumption in the classical leaching procedure, an almost selective $\mathrm{Cu}$ leaching has first been performed using adipic acid followed by bioleaching of uranium . In both techniques, the optimum working conditions have been determined using an ore ground to-200 mesh size. Accordingly for $\mathrm{Cu}$ leaching , 0.5 mole adipic acid was used at $50{ }^{\circ} \mathrm{C}$ for $30 \mathrm{~min}$. in a $\mathrm{S} / 1$ ratio of $1 / 3$ resulting in leaching efficiency ex-

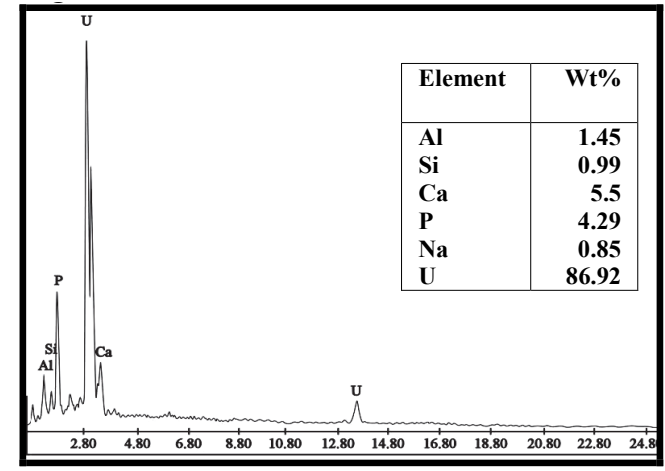

Fig. 8: ESEM-EDX analysis of ammonium diuranate precipitated from Amberlite IRA- 400 resin eluat at $\mathrm{pH} 5.5$

ceeding $95 \%$ and only about $6.5 \%$ U. In the succeeding bioleaching step, $\mathrm{U}$ was leached using A. niger metabolites in a $S / 1$ ratio $1 / 2$ for 24 hours. Under these conditions, a U leaching efficiency of about $82 \%$ has been realized . Proper, marketable pure $\mathrm{Cu}$ and $\mathrm{U}$ products have been prepared as $\mathrm{Cu}(\mathrm{OH})_{2}$, via $\mathrm{Cu}$ adipate crystallite and $\left(\mathrm{NH}_{4}\right)_{2} \mathrm{U}_{2} \mathrm{O}_{7}$ via anion exchanger resin. From all the obtained results, it has been possible to formulate the tentative flowsheet on Fig.(9).

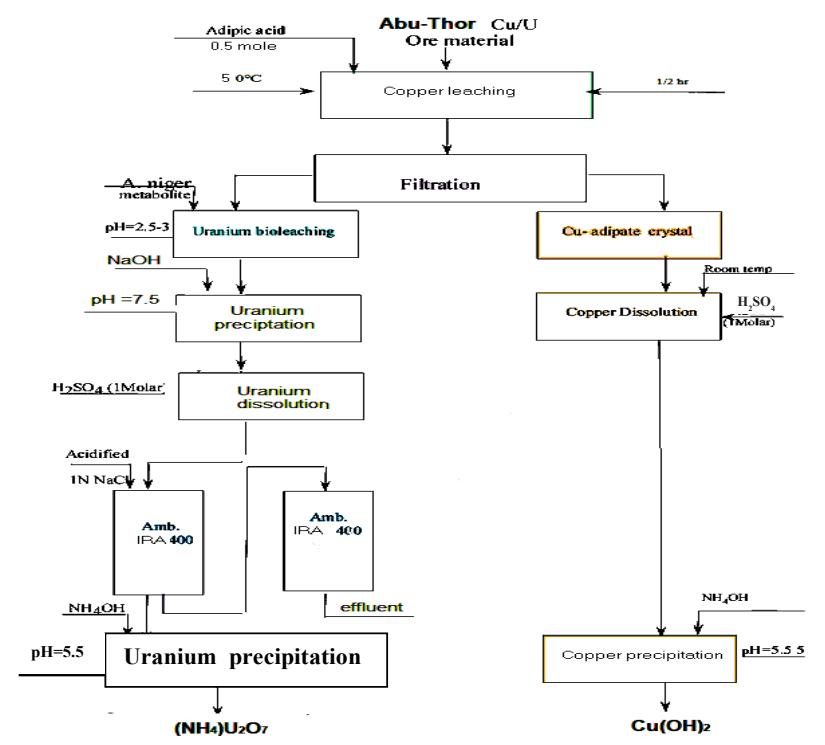

Fig.9: A tentative flowsheet for the recovery of $\mathrm{U}$ and $\mathrm{Cu}$ from Abu Thor technological sample hosted in the carbonate -rich latosol horizon of Um-Bogma Formation 


\section{REFERENCES}

Abdel Monem,A.; El Aassy, I.E.; Hegab, O.; El Fayoumy, I. and El Agami, N.,1997. Gibbsite, uranium and copper mineralizations, Um Bogma area, Southwestern Sinai, Egypt. Sedimentology of Egypt, 5,117-132.

Aita, S.K.,1996. Geological, mineralogical and geochemical studies on some radioactive anomalies of the Paleozoic sediments of Um Bogma area, West Central Sinai, Egypt. M.Sc. Thesis, Fac. Sci.,Cairo Univ., Egypt, 262p.

Amer, T.E.; EL-Hazek , M.N.; Abd EL-Fattah , N.A.; EL-Shamy , A.S.; Abd-Ella , M. W., and EL-Shahat, M.F. ,2010. Processing of Abu Zenima mineralized gibbsite ore material for the recovery of aluminium, zinc and individual light rare earth oxides. J. Middle East Radioactive Isotopes Center, 40(2).

Amin , M.M.,2008. Fungal activity for solubilization and accumulation of uranium from various grade and subsequent chemical recovery. Ph.D thesis, Fac. Sci., Menoufia Univ,183p.

Bassi, P.S., and Kalsi, P. C.,1977. Thermal decomposition of $\mathrm{Cu}(\mathrm{II})$ adipate , J. Thermal Anal., $13,363-368$

Bassi , P.S.; Chopra, O.S., and Gupta, B.R.,1988. Studies in solid state reactions between basic copper carbonate with cinnamic, succinic and adipic acids. Thermochimica Acta, 124, 197203.

Brandle, H.; Bosshar, R., and Wegmann, N.,2001. Computer munching microbes metal leaching from electronic scrap by bacteria and fungi. Hydrometallurgy, 59, 319-326. Burken, A. R.,1950). J., Chem. Soc., 122., c.f: Bassi, P. S. and. Kalsi, P. C(1978): Thermal decomposition of $\mathrm{Cu}(\mathrm{II})$ adipate, J. Thermal Anal. 13, 363-368

Castellan, A.; Bart, J.C.J.; and Cavallaro, S.,1991. Industrial production and use of Adipic acid. Catal. Today, 9(3), 237-254.

Dabbour, G.A., and Mahdy, M.A.,1988. Mineralogical studies on the Carboniferous uraniferous sediments West Central Sinai, Egypt. 4th Conf. Nuc. Sci. and Appl. Cairo, Egypt, 1, 230-237.

Davis, D.D.; Kemp, D.R., and Kirk-Othmer, 1991. Encyclopedia of Chemical Technology, 4th ed., 1, Wiley, New York

El- Hazek, M.N.; Ahmed, F.Y. ; El Kasaby, M.A., and Attia, R.M.,2008. a Sulfuric acid leaching of polymetallic $\mathrm{Abu}$ Zeneima gibbsite-shale. Hydrometallurgy, 34-39.

Ehrlich, H. L., and Brierley, C. L.,1990. Microbial mineral recovery. Enviro. Biotechnology Series, Mc Graw Hill, New York, USA. . 454 p.

El Reedy, M.W.; Mahdy, M.A.; El Aassy, I.E, and Dabbour, G.A.,1988. Geochemistry studies of some uraniferous sedimentary rock varieties of West Central Sinai, Egypt. 4thConf. Nuc.Sci. and Appl., Cairo, Egypt, 1, 224-229.

El Sharkawi, M.A.; El Aref, M.M., and Abd El Motelib, A.,1990. Syngenetic and palaeokarstic copper mineralization in the Paleozoic platform sediments of West Central Sinai, Egypt. BL: Sediment- Hosted Mineral Deposits (Parnell, J. et al., eds.) Int. ASS. Sediments, 159-172.

Fessenden,R.J., and Fessenden, J.S.,1982. Organic chemistry. Library of Congress cataloge.2nd ed., $1067 \mathrm{p}$.

Hefnawy, M. A.; El-Said, H. M., and Maisa, A.,2002. Fungal leaching of uranium from its geological ores in Alluga area, West Central Sinai, Egypt. OnLine J. Biol.,2, 346-350.

Hefnawy, M. A.; Hashad, A. M., and Maisa, A.,2003. Optimization of uranium leaching parameters by A.terreus and P. spinulosum. Afric. J. mycology and biotechnology, 1,17-34.

Hilmy, M.E., and Mohsen, L.,1965. Secondary copper minerals from West Central Sinai.J. Geol. UAR ,9,1-12.

Hussein, H.;Abd El Monem, A.; Mahdy, M.; El Aassy, I., and Dabbour, G.,1992. On the genesis of surficial uranium occurrences in West Central Sinai, Egypt. Ore Geol. Rev., 7, 125-135. 
Ibrahium, H. A.,2007. Bioleaching of some heavy metals by microorganisms from some different ores in Egypt. Ph.D. thesis, Fac. Agric., Ain Shams Univ ,103p.

Merritt, R.C.,1971.Extractive metallurgy of uranium. Colorado school of Mines Research Inst., olden Clorado, $270 \mathrm{p}$.

Mira, H. I., and Aita,S.K.,2009. Remobilization of uranium and copper through karstification processes; A case study in in Abu Thor locality , Um Bogma region, West Central Sinai, Egypt . Ann. Geol. Surv. Egypt. , 31, 21-42.

Oldaham, C.,1987. Comprehensive coordination chemistry. Wilkinson, G., Gillard, G., McCleverty, J.A., (eds), 2. Pergamon Press, London, $435 \mathrm{p}$.
Preuss, A., and Kurrin ,R.,1965. A general survey of types and characteristics of ion exchange resin used in uranium recovery c.f. Technical reports series no. 359. inter. atomic energy agency, vienna (1965)

Saeed, S.; Bhatti H.N., and Bhatti, T.M.,2002. Bioleaching studies of Rock phosphate. Using Aspergillus niger .on line J. Biol. Sci., 2 (2): 76 -78.

Shapiro, L., and Brannock, N.W., 1962. Rapid Analysis of Silicate, Carbonate and Phosphate Rocks. U.S. Geol. Surv. Bull., 114 A, 65p.

Shek C.H.; Lai J.K.L.; Gu, T.S., and Lin, G.M.,1997. Nanostruct Mater, 8(5), 605-610.

Suresh, E.,2009. Crystal Structure of Tetrakis Imidazole Copper(II) Diadipate Complex. J Chem Crystallogr , 39,104-107.

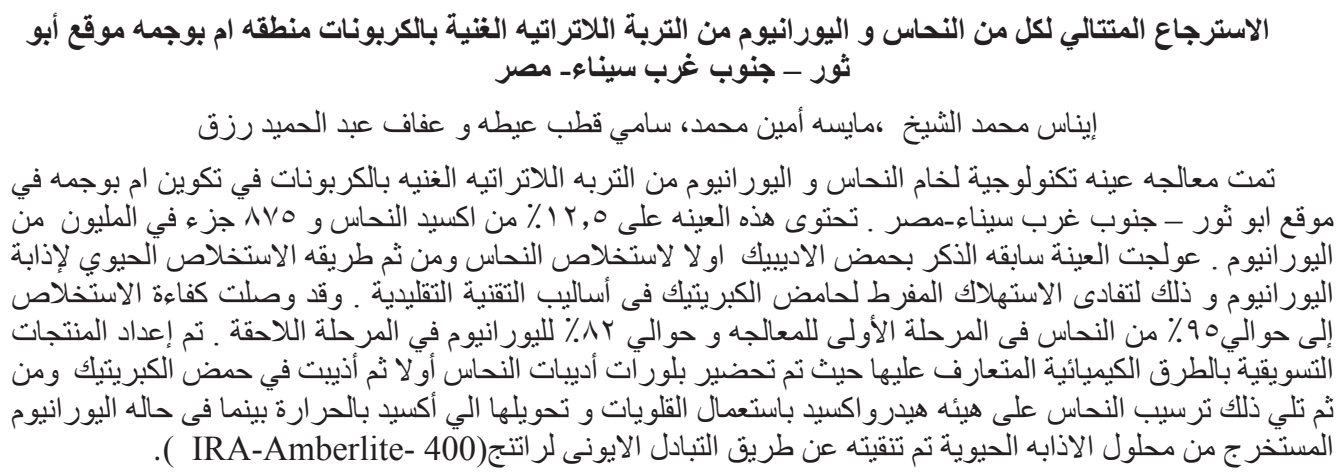

